\section{Editorial Pointers}

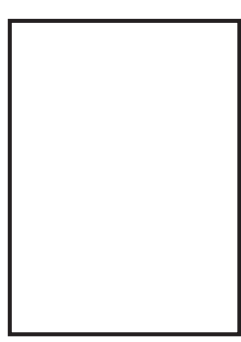

WHEN EMBEDDED NETWORK SENSING SHIFTED from the laboratory to the natural environment, it was done under the meticulous design of scientists. Computer nodes embedded in the physical world would observe ecosystems, collecting field data intended to give researchers an unprecedented window into how nature works. But like most technologies with great repurposing potential, networked sensing is moving at a far faster and fortuitous pace into the urban landscape, driven more by opportunism than real science.

In this month's cover story "Urban Sensing: Out of the Woods," Dana Cuff, Mark Hansen, and Jerry Kang of UCLA trace how urban sensing will be "unleashed" in city settings through the proliferation of cell phones, GPS technologies, and RFID tags. Collecting data on citizens brings great opportunities as well as a host of ethical and privacy concerns. The authors call for a collaborative effort among scientists, artists, urbanists, and business people to establish a trustworthy infrastructure for city-based networked sensing.

\section{IN OTHER TECHNOLOGIES AND SERVICES SPAWNED BY CELL PHONES} and mobile devices, Junglas and Watson demonstrate the differences between location-tracking and location-aware services. And Soh and Tan examine how the mobile games market's enormous business opportunity also comes with a significant threat to the incumbent billion-dollar gaming industry.

Liping Zhao offers a word of advice for today's programmer: The next time you design a program, think carefully about which symmetries to keep and which ones to break, and why. In "Applications of Critical Thought for IT Professionals," Bernd Carsten Stahl and Carole Brooke offer some "critical" guidelines for IT professionals that require effort, resources, and the courage to question oneself.

Two articles this month focus on security weaknesses among business practices and the global user community. Wright et al. present a fictional scenario of daily life in a world networked through ambient intelligence. The year is 2018 and the story unravels a tale of corporate ethical choices. In the end, they wonder, is this world of 10 years hence really any different from today's? Meanwhile, Larose, Rifon and Enbody speculate how to encourage Internet users to assume more responsibility for protecting themselves online.

In this month's "Viewpoint," Chenglie Hu argues the study of data types is crucial for learning programming. Novices, he says, who do not learn data types the correct way will face great difficulty trying to learn object-oriented programming. Phillip Armour highlights the pitfalls of "accurately" estimating software projects in "The Business of Software." And, on page 22, ACM is pleased to announce its newly inducted ACM Fellows.

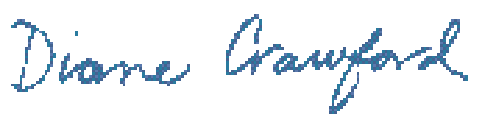

EDITOR
COMMNICATIONS

A monthly publication of the ACM Publications Office

ACM

2 Penn Plaza, Suite 701

New York, NY 10121-0701 USA

(212) 869-7440 FAX: (212) 869-0481

Group Publisher: Scott Delman

Editor: Diane Crawford

Managing Editor: Thomas E. Lambert

Senior Editor: Andrew Rosenbloom

Editorial Assistant: Zarina Strakhan

Copyright: Deborah Cotton

\section{Contributing Editors}

Phillip G. Armour; Hal Berghel;

Michael A. Cusumano; Peter J. Denning;

Robert L. Glass; Seymour Goodman;

Rebecca Mercuri; Peter G. Neumann;

Pamela Samuelson; Meg McGinity Shannon

Art Director: Caren Rosenblatt Production Manager: Lynn D'Addesio

\section{Advertising}

ACM Advertising Department

2 Penn Plaza, Suite 70I, New York, NY I0I2I-070I

(2I2) 869-7440; Fax: (2I2) 869-048I

\section{Director of Media Sales:}

Jonathan M. Just: jonathan.just@acm.org

For the latest media kit-including rates - contact:

Graciela Jacome: jacome@acm.org

\section{Contact Points}

CACM editorial: crawford_d@acm.org

Copyright permission: permissions@acm.org

Calendar items: calendar@acm.org

Change of address: acmcoa@acm.org

\section{Communications of the ACM}

(ISSN 000I-0782) is published monthly by the ACM, 2 Penn Plaza, Suite 70I, New York, NY

10121-0701. Periodicals postage paid at

New York, NY I000I, and other mailing offices.

POSTMASTER: Please send address changes to

Communications of the ACM, 2 Penn Plaza,

Suite 70I, New York, NY I0I2I-070I USA

Printed in the U.S.A.

Association for Computing Machinery 


\section{AC The Association for Computing Machinery}

ACM (founded 1947) is an international scientific and educational organization dedicated to advancing the art, science, engineering, and application of information technology, serving both professional and public interests by fostering the open interchange of information and by promoting the highest professional and ethical standards.

\section{Executive Director and CEO: John White Director, ACM U.S. Public Policy Office: Cameron Wilson}

Deputy Executive Director and COO: Patricia Ryan Director, Office of Information Systems: Wayne Graves Director, Office of Financial Services: Russell Harris Financial Operations Planning: Darren Ramdin

Director, Office of Membership: Lillian Israel

Director, Office of Publications: Mark Mandelbaum Deputy Director: Bernard Rous Deputy Director, Magazine Development: Diane Crawford Publisher, ACM Books and Journals: Jono Hardjowirogo

Director, Office of SIG Services: Donna Cappo

\begin{tabular}{|c|c|}
\hline $\begin{array}{r}\text { ACM Council } \\
\text { President } \\
\text { Vice-President } \\
\text { Secretary/Treasurer } \\
\text { Past President } \\
\text { Chair, SGB Board } \\
\text { o-Chairs, Publications Board }\end{array}$ & $\begin{array}{l}\text { Stuart I. Feldman } \\
\text { Wendy Hall } \\
\text { Alain Chesnais } \\
\text { David A. Patterson } \\
\text { Joseph A. Konstan } \\
\text { Ronald Boisvert, } \\
\text { Holly Rushmeier }\end{array}$ \\
\hline
\end{tabular}

Members-at-Large: Michel Beauduoin-Lafon (2000-2008);

Bruce Maggs (2006-2010); Barbara Ryder (2000-2008); Kevin Scott (2006-20I0); Jeannette Wing (2006-20I0); David S. Wise (2004-2008).

SGB Council Representatives:

Norman Jouppi (2006-2007); Robert A. Walker (2006-2008);

Alexander Wolf (2005-2007)

\section{Board Chairs and Standing Committees}

Education Board: Andrew McGettrick/Eric Roberts SGB Board: Joseph A. Konstan; Membership Services Board: Terry Coatta; Publications Board: Ronald Boisvert, Holly Rushmeier Professions Board: Stephen R. Bourne USACM Committee: Eugene Spafford

\section{SIG Chairs}

SIGACCESS: Vicki Hanson SIGACT: Richard Ladner; SIGAda: John McCormick; SIGAPL: Guy R. Larocque; SIGAPP: Barrett Bryant; SIGARCH: Douglas C. Burger; SIGART: Maria Gini; SIGBED: Lothar Theile;

SIGCAS: Florence Appel; SIGCHI: Julie Jacko; SIGCOMM: Mark Crovella; SIGCSE: Barbara Boucher Owens; SIGDA: Diana Marculescu; SIGDOC: Brad Mehlenbacher; SIGecom: David Pennock SIGEVO: Darrell Whitley; SIGGRAPH: G. Scott Owen; SIGIR: Elizabeth Liddy; SIGITE: Han Reichgelt; SIGKDD: Gregory Piatetsky-Shapiro; SIGMETRICS: Carey Willliamson; SIGMICRO: Erik Altman; SIGMIS: Janice Sipior; SIGMOBILE: David B. Johnson; SIGMOD: Raghu Ramakrishnan; SIGMULTIMEDIA: Klara Nahrstedt; SIGOPS: Doug Terry; SIGPLAN: Kathleen Fisher; SIGSAC: Virgil D. Gligor; SIGSAM: Mark W. Giesbrecht; SIGSIM: Simon J.E. Taylor; SIGSOFT: William G. Griswold; SIGUCCS: Leila Lyons; SIGWEB: Ethan Munson

For information from Headquarters: (212) 869-7440

ACM U.S. Public Policy Office:

Cameron Wilson, Director

1100 Seventeenth St., NW

Suite 507

Washington, DC 20036 USA

$+|-202-659-97| \mid$-office

+|-202-667-1066-fax

wilson_c@acm.org

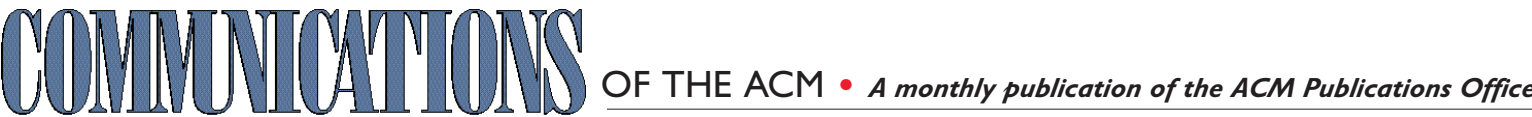

ACM, 2 Penn Plaza, Suite 70I, New York, NY I0I2I-070I USA (2I2) 869-7440 FAX: (2I2) 869-048I

\section{Editorial Advisory Board}

Gordon Bell; Hal Berghel; Grady Booch;

Nathaniel Borenstein; Vinton G. Cerf;

Kilnam Chon; Jacques Cohen; Larry L. Constantine;

Jon Crowcroft; Peter J. Denning; Mohamed E. Fayad;

Usama Fayyad; Christopher Fox; Ravi Ganesan;

Don Hardaway; Karen Holtzblatt; Pattie Maes;

Eli Noam; Cherri Pancake; Yakov Rekhter;

Douglas Riecken; Ted Selker; Dennis Tsichritzis: Ronald Vetter

\section{Publications Board}

Co-Chairs: Ronald F. Boisvert and Holly Rushmeier Board Members: Gul Agha; Michel BeaudouinLafon; Carol Hutchins; Mary Jane Irwin; Ee-ping Lim; Keith Marzullo; M. Tamer Ozsu; Vincent Shen; Mary Lou Soffa; Ricardo Baeza-Yates

\section{ACM Copyright Notice}

Copyright $@ 2008$ by Association for Computing Machinery, Inc. (ACM). Permission to make digital or hard copies of part or all of this work for personal or classroom use is granted without fee provided that copies are not made or distributed for profit or commercial advantage and that copies bear this notice and full citation on the first page.
Copyright for components of this work owned by others than ACM must be honored. Abstracting with credit is permitted. To copy otherwise, to republish to post on servers, or to redistribute to lists, requires prior specific permission and/or fee. Request permission to publish from: Publications Dept. ACM, Inc. Fax +I (2I2) 869-048I or email <permissions@ acm.org>

For other copying of articles that carry a code at the bottom of the first or last page or screen display, copying is permitted provided that the per-copy fee indicated in the code is paid through the Copyright Clearance Center, 222 Rosewood Drive, Danvers, MA 01923, 508-750-8500, 508-750-4470 (fax).

\section{Subscriptions}

Annual subscription cost is included in the society member dues of $\$ 99.00$ (for students, cost is included in $\$ 40.00$ dues); the nonmember annual subscription is $\$ 189.00$ See top line of mailing label for subscription expiration date coded in four digits: the first two are year, last two, month of expiration. Microfilm and microfiche are available from University Microfilms International, 300 North Zeeb Road, Dept. PR, Ann Arbor, MI 48I06; (800) 521-0600.
Single Copies are $\$ 8$ to members and $\$ 17$ to nonmembers. Please send orders prepaid plus $\$ 7$ for shipping and handling to ACM Order Dept., P.O. Box II4I4, New York, NY 10286-1414 or call (2I2) 626-0500. For credit card orders call (800) 342-6626. Order personnel on duty 8:30-4:30 EST. After hours, please leave message and order personnel will return your call.

Notice to Past Authors of ACM-Published Articles ACM intends to create a complete electronic archive of all articles and/or other material previously published by ACM. If you were previously published by ACM in any journal or conference proceedings prior to 1978, or any SIG newsletter at any time, and you do not want this work to appear in the ACM Digital Library, please inform permissions@acm.org, stating the title of the work, the author(s), and where and when published. 